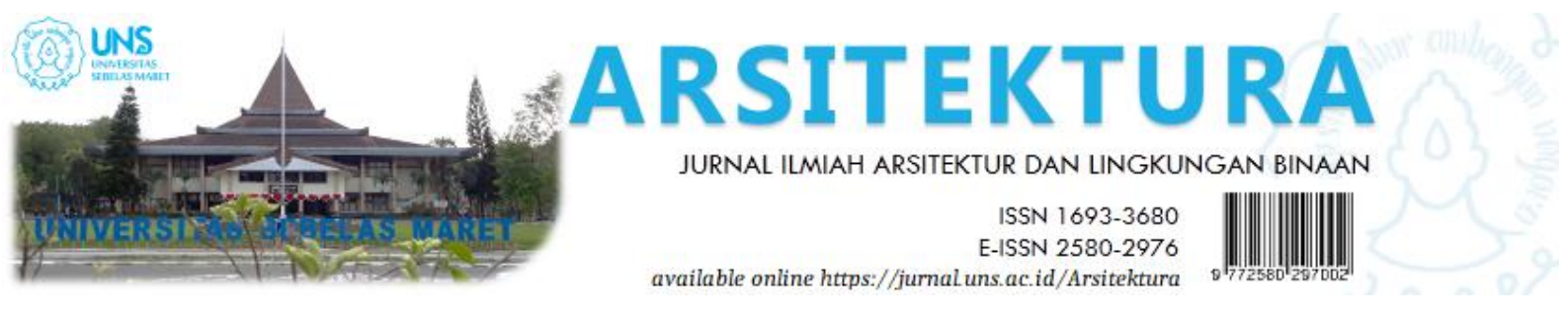

Volume 19 Issue 2 October 2021, pages:195-204

\title{
Appropriate Site Development in the Application of the Green Building Concept: An Evaluation of the Planning of Gianyar Public Market
}

\author{
Ni Luh Eka Janiawati ${ }^{1}$, Ni Ketut Agusintadewi ${ }^{2 *}$, Widiastuti ${ }^{3}$ \\ Master of Architecture Program, Faculty of Engineering, Universitas Udayana ${ }^{1}$ \\ Master of Architecture Program, Faculty of Engineering, Universitas Udayana ${ }^{2 *}$ \\ nkadewi@unud.ac.id \\ Master of Architecture Program, Faculty of Engineering, Universitas Udayana ${ }^{3}$
}

DOI: https://doi.org/10.20961/arst.v19i2.47689

Received: January 15,2021 Revised: June 27,2021 Accepted: July 28,2021 Available online: October 30,2021

\begin{abstract}
Appropriate Site Development is one of the Greenship criteria for maintaining or expanding urban greenery in order to improve microclimate quality, decrease CO2 and other pollutants, avoid soil erosion, reduce drainage system loads, and keep the balance between clean water and groundwater systems. The GREENSHIP concept is a solution to the decline of the green spaces of Gianyar regency, which has been due to the construction of hotels and villas for tourism. The Government of Gianyar Regency in Bali Province is committed to applying the concept by planning Gianyar Public Market as the first public facility that uses the idea. This study evaluated whether the application of the Green Building concept, particularly the one in the category of Appropriate Site Development, will be beneficial for the users and the surrounding environment. The evaluation used mixed-methods, which incorporated a case study approach. Two key persons were interviewed. The collected interview data combined with the secondary data were processed with the GREENSHIP rating tools. Results of the evaluation show that, in the category of Appropriate Site Development, the planning of Gianyar Public Market obtains $41.18 \%$ points. It means that the planning has not yet adequately fulfilled the criteria. Therefore, some efforts and improvements need to be taken and made to fulfill the criteria of the categories in which the planning has not yet obtained maximum points. One of such categories is technology application.
\end{abstract}

Keywords: Appropriate Site Development; public market; the Green Building Concept; the GREENSHIP criteria

\section{INTRODUCTION}

Development that exploits natural resources and disregards environmental capability and the carrying capacity of the environment may contribute to the decline in environmental quality (Mahi, 2017). A number of factors for the decline relate to human activities. One of the ways to reduce the negative impact of such development is the application of the Green
Bulding concept. The environmentally friendly building concept or the Green Building concept (Firsani and Utomo, 2012) is a concept that plays a role in sustainable development and a trending topic in the international construction world (Teddy, Priatman, and Susilo, 2018).

Eco-friendly principles are implemented in the projects, structures, and constructions, as well as the operational and managerial systems, of 
green buildings. With regard to this, the regulation of the Ministry of Environment Number $8 / 2010$ was made to address climate change effects. A green building uses a minimum of natural resources, utilizes the land wisely, reduces environmental impacts, and creates healthy and comfortable indoor air quality (Nasir, 2016). Green Building Council Indonesia (GBCI) has determined six criteria for reviewing green buildings. One of the criteria is appropriate site development (Anggunmulia et al., 2015).

The application of the green building concept in Indonesia is still near to the ground. Only two regions have regulations regarding the implementation of the Green Building concept (Rinaldi, 2019), namely the Province of the Special Capital Region of Jakarta and Bandung City. The Government of Semarang City is currently discussing and drafting such regulations. The fact that very few regions in Indonesia have applied the Green Building concept is regrettable, considering the decline in environmental quality contributed by unsustainable development and the fact that the concept has become a trend in many developed countries (Rinaldi, 2019).

Green buildings may reduce negative impacts on the environment and public health (Zainol et al., 2015). Some of the criteria for green buildings are appropriate site development and thermal and acoustic comfort. Appropriate site development may positively affect the condition of buildings and the surrounding environment. According to GREENSHIP (2013), the positive impacts of appropriate site development on buildings and the surrounding environment are the maintenance or expansion of city greenness, the reduction of $\mathrm{CO} 2$ and other pollutants, the prevention of soil erosion, the reduction of drainage load, the reduction of heating, and the reduction of noise. Appropriate site development is one of the basic principles in green architecture planning, in the section of respect for the site, which states that a building must not harm the condition of the original site and may make only minimum site changes (Arafat and Syamsiyah, 2013). The inappropriate development of a building's site will be detrimental to the building occupants and the surrounding environment. Nowadays, the Green Building concept is a solution of global warming, which is already very worrying. However, its implementation has faced many challenges.

The Green Building concept is present and becomes a necessity in the current global warming phenomenon. The concept is considered one solution to reduce environmental damage and minimize carbon emissions from the construction sector. Due to the rapid infrastructure development in the tourism sector in Gianyar Regency, which is reflected in the construction of many hotels and villas, the green space of the regency has progressively declined. If the situation is not addressed properly, the green space will be in a critical condition.

Gianyar Regency is committed to addressing negative impacts on the environment through the implementation of the Green Building concept. Gianyar Public Market is the first public building whose design is developed based on the concept. Therefore, it would be fruitful to examine how far the Planning of Gianyar Public Market has implemented the Green Building concept to improve the efficiency of the resources used in the building, such as energy and material resources, and reduce the negative impacts of the construction.

This study aims to evaluate the implementation of the Green Building concept in the category of appropriate site development in the Planning of Gianyar Public Market based on GREENSHIP rating tools. Results of the evaluation are used as the basis for formulating recommendations to increase the points of the market's planning.

\section{RESEARCH METHOD}

Indonesia is also committed to educating the public by spreading environmental awareness. This can be seen in the establishment of Green Building Council Indonesia (GBCI) in 2009. GBCI is a non-governmental and non-profit organization. One of its main programs is the certification of green buildings in Indonesia by using assessment tools developed specifically for Indonesia called GREENSHIP rating tools (Surjana and Ardiansyah, 2013). GBCI is a member of World Green Building Council (WGBC), which is based in Toronto, Canada. The organization has 94 member countries, and 
there is only one Green Building Council (GBC) in each member country (Amalia et al., 2018). GBCI has published rating tools for the certification of environmentally friendly buildings (new buildings, existing buildings, and interiors).

This study investigated the Planning of Gianyar Public Market, which is located on Ngurah Rai Street number 75, Gianyar Regency, Bali Province. The study used mixed-methods with a case study approach. Data collection was carried out through observations, interviews with informants, documentation, and field measurements. The collected data were analyzed to establish factors related to the case which may be considered to draw accurate conclusions (Sutedi, 2009).

Two key persons were interviewed. They are the commitment making official of the Department of Human Settlements and Public Works of Gianyar Regency and the consultant planner of public market development in Gianyar Regency.

Furthermore, the study also used data secondary to be combined with the other data in order to create triangulation. The secondary data used are:

1. the site plan drawing,

2. the technical specification of the material quality that refers to the $\mathrm{Q} \& \mathrm{~A}$ form provided by the developer and image data,

3. the Regulation of the Ministry of Public Works Number 14/PRT/M/2013 on the Standards and Guidelines for the Procurement of Construction Work and Consultancy Services,

4. the Regulation of the Ministry of Public Works Number 5/PRT/M/2008 on Green Open Space,

5. the Regulation of the Ministry of Environment Number 8/2010,

6. the Regulation of the Ministry of Home Affairs Number 1/2007 on the Management of Green Open Space for Urban Areas, and

7. the Regulation of the Government of Gianyar Regency Number $16 / 2012$ on the Spatial Plan for Gianyar Regency Year 2012-2023.

The interview data were analyzed by considering the fulfilment of the criteria specified in GREENSHIP rating tools. The assessment system used benchmarks incorporating some assessment aspects and used categories with each of them having a value (a credit point). Each measure was related to a specific point load obtained through several calculations and was processed to carry out the assessment of the application of the Green Building concept (Ratnaningsih et al., 2019). Based on GREENSHIP rating tools, GREENSHIP HOME self-assessment may help us determine if a building can be classified as a green one or not (Nastiti et al., 2020).

The analysis was focused on the category of appropriate site development with seven criteria as shown in Table 1. The assessment was conducted by using points specified by GBCI. Then, recommendations were made to increase the value of the building under investigation.

Table 1 shows that there are two types of criteria in the category of appropriate site development, namely prerequisite criteria and credit criteria. Prerequisite criteria are the criteria that exist in each category and that have to be fulfilled before a further assessment is conducted based on credit criteria and bonus criteria. Prerequisite criteria represent the minimum standards of environmentally friendly buildings. If one of the criteria is not fulfilled, the credit and bonus criteria in all the categories cannot be assessed. Prerequisite criteria, unlike the other criteria, do no have values. Meanwhile, credit criteria are criteria that exist in each category and do not have to be fulfilled. If some criteria are fulfilled, the building under investigation get points. On the other hand, if some criteria are not fulfilled, the building will not get any point (GREENSHIP, 2013).

Table 1. The Criteria and Categories of Appropriate Site Development (ASD)

\begin{tabular}{llcc}
\hline Category and Criteria & $\begin{array}{c}\text { Maximum } \\
\text { Criteria } \\
\text { Value }\end{array}$ & $\begin{array}{c}\text { Description per } \\
\text { Category }\end{array}$ \\
\hline ASD P & Basic Green Area & $\mathrm{P}$ & $\begin{array}{c}1 \text { prerequisite } \\
\text { criteria }\end{array}$ \\
ASD 1 & Site Selection & 2 & 7 credit criteria \\
ASD 2 & $\begin{array}{l}\text { Community } \\
\text { Accessibility }\end{array}$ & 2 & \\
ASD 3 & $\begin{array}{l}\text { Public } \\
\text { Transportation }\end{array}$ & 2 & \\
ASD 4 & Bicycle Facility & 2 & \\
\hline
\end{tabular}




\begin{tabular}{llcc}
\hline Category and Criteria & $\begin{array}{c}\text { Maximum } \\
\text { Criteria } \\
\text { Value }\end{array}$ & $\begin{array}{c}\text { Description per } \\
\text { Category }\end{array}$ \\
ASD 5 & Site Landscaping & 3 & \\
ASD 6 Micro Climate & 3 & \\
ASD 7 Stormwater & 3 & \\
& $\begin{array}{l}\text { Management } \\
\text { Total Score of ASD }\end{array}$ \\
Categories & 17 & $16.8 \%$ \\
\hline
\end{tabular}

Source: the Greenship for New Buildings version 1.2, 2013

Appropriate site development is one of the basic principles of green architecture planning, in the section of respect for the site, which states that buildings must not damage the condition of the original site and may make only minimum site changes (Arafat and Syamsiyah, 2015). Appropriate site sevelopment (ASD) with a maximum total value of 17 or $16.8 \%$ of the total value of the whole aspect has seven sub-criteria as follows:

1. ASD 1 Site Selection avoids the development in green areas and the opening of new land.

2. ASD 2 Community Accessibility encourages development in places with connectivity networks and improves building usage to facilitate the community in carrying out daily activities and avoiding motor vehicles.

3. ASD 3 Public Transportation encourages building users to use mass public transportation and reduce the use of private vehicles.

4. ASD 4 Bicycle Facility encourages building users to use bicycles by providing adequate facilities to reduce the use of motor vehicles.

5. ASD 5 Site Landscaping maintains or expands the city's greenness to improve the microclimate quality, reduce $\mathrm{CO}$ and other pollutants, prevent soil erosion, reduce the burden of drainage systems, and maintain clean water balance and groundwater systems.

6. ASD 6 Micro Climate improves the quality of the microclimate around the building, which affects, among other things, human comfort and the habitat around the building.

7. ASD 7 Stormwater Management reduces the burden of the environmental drainage system from a quantity of rainwater runoff with an integrated rainwater management system.
If the above criteria are fulfilled according the GREENSHIP rating parameters, the building under evaluation will get a value. On the other hand, when those criteria are not fulfilled, the building will not get any value (Greenship, 2013).

Figure 1 and Figure 2 show the research setting. The area of Gianyar Public Market is 10,060 m2 (based on the certificate). Its Basic Building Coefficient is $4,704 \mathrm{~m} 2$ or $47 \%$.
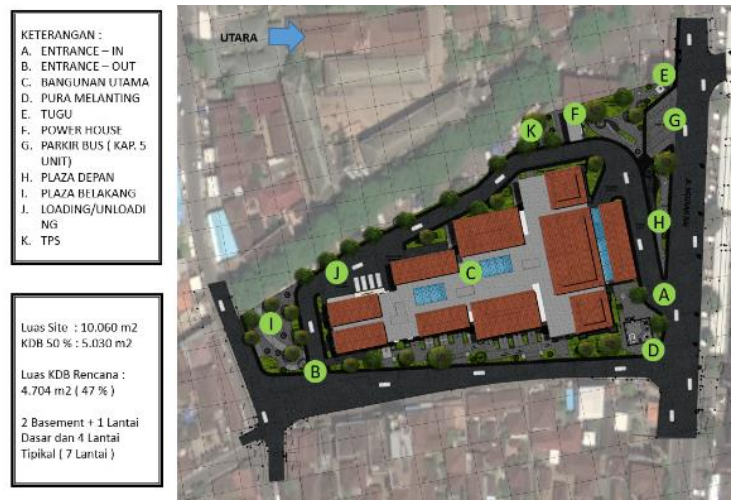

Figure 1. Location of the building

Source: Document of Gianyar Public Market Plan, Department of Public Works and Spatial Planning of Gianyar Regency, 2019
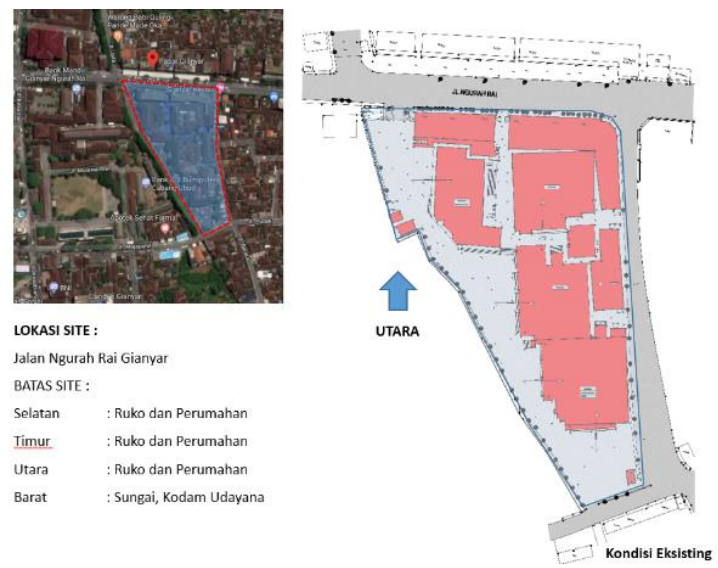

Figure 2. The Site Area and the Calculation of Basic Building Coefficient

Source: Document of Gianyar Public Market Plan, Department of Public Works and Spatial Planning of Gianyar Regency, 2019

\section{RESULTS AND DISCUSSION}

According to WGBC data, in the world, buildings contribute to $33 \%$ of $\mathrm{CO}_{2}$ emissions and consume $17 \%$ of clean water, $25 \%$ of wood products, $30-40 \%$ of the used energy, and $40-$ 
$50 \%$ of the used raw materials for construction and operation (Kurniati, Sucipto, and Murtiono, 2014). Only a few companies and property developers apply green building principles because the initial costs are higher than those required for buildings that do not apply the Green Building concept (Andini and Utomo, 2014). Buildings that apply the concept require higher construction costs because there are some important aspects that have to be fulfilled during the construction in order that the building becomes a green one. Each criterion of a green building affects the costs of its construction, such as the use of materials that has to pay attention to their types and their impacts on the environment (Dianita, Lilo, and Sucipto, 2014). With a sustainable concept, green buildings have good long-term effects on the environment. In addition, the energy costs will be cheaper, so that the high construction costs can be compensated by the reduced energy costs or the costs incurred during the buildings' service life.

The Green Building concept is applied to increase the efficiency of the use of energy, water, and material resources in buildings and reduce the negative impacts of buildings on the people's health and the environment during the buildings' life cycle. This condition can be achieved through better design and construction, operational system, maintenance, and waste management (Frej, Browning, and Urban Land Institute, 2005). Green building offers lower-level risks and positively responds to the environment (Shiers, 2000).

Results of the observation and measurement of the Planning of Gianyar Public Market show that the prerequisite category of the essential green space has been fulfilled. The landscape's area is $10 \%$ of the total area of the market site and it is in the forms of softscape, which is free from building structures, and hardscape (simple garden structures). It is more than $10 \%$ of the total land area. In line with the Regulation of the Minister of Home Affairs Number 1/2007 Article 13 (2a), 50\% of the area is covered by the vegetation of small, medium, and large trees, half-tree shrubs, and shrubs in their mature size. Types of the plants grown in the area are in line with the Regulation of the Minister of Public Works Number
5/PRT/M/2008 on Green Open Space, Article 2.3.1 on Criteria of the Vegation for Yards.

Table 2 shows an assessment of the site selection categories. The complex of Gianyar Public Market, which is located on Jalan Ngurah Rai, Gianyar, is equipped with city facilities and infrastructure, namely pedestrian paths and roads, clean water, telephone, electricity, drainage, waste, and fibre optic networks. With the fulfilment of the minimum benchmark requirements of 8 city infrastructure and facilities, the sub-criterion of site selection gets one point.

Table 2. Assessment of the Category of Site Selection (ASD1)

\begin{tabular}{llcc}
\hline \multicolumn{1}{c}{ Benchmark } & PM & BL & Target \\
\hline 1A $\begin{array}{l}\text { Selecting a development } \\
\text { area that is equipped with } \\
\text { a minimum of } 8 \text { out of the } \\
12 \text { city infrastructure and }\end{array}$ & & 1 & 1 \\
1B $\begin{array}{l}\text { facilities. } \\
\text { Selecting a development } \\
\text { area with the provisions of }\end{array}$ & & & \\
KLB> 3 \\
Carrying out revitalization \\
and development on a lot \\
of land that has a negative \\
value and that is unused \\
because it used to be a site \\
for some building or \\
because of the negative \\
impact of development.
\end{tabular}

The availability of public facilities and pedestrians' access around the building becomes one of the benchmarks in this subcriterion. The planning of Gianyar Public Market has implemented 2 out of the required 4 criteria (see Table 3 ) with the following data.

1. The first benchmark is that there are at least 7 public facilities whose distance from the site via the main road is within $1,500 \mathrm{~m}$, namely a) Bank BPD Bali, which is \pm 210 meters away; b) Bank Mandiri Gianyar, which is \pm 130 meters away; c) The Grand Mosque of Al-A'la Gianyar, which is \pm 410 meters away; d) Healthy Farma Pharmacy, which is \pm 300 meters away; e) Astina Field, which is \pm 500 meters; f) Gianyar Cultural Center, which is \pm 270 meters; and $\mathrm{g}$ ) Clandys Gianyar, which is \pm 500 meters away. 
2. The second benchmark is the availability of pedestrian access that leads from the site to areas other than the main road, which may be a secondary road and/or an adjacent area belonging to another owner, so that there is pedestrian access from the site to at least three public facilities within the distance of $300 \mathrm{~m}$. The assessment based on the first benchmark shows that three facilities have met the requirement. Meanwhile, the second benchmark gets 1 point.

Table 3. Assessment of the Category of Community Accessibility (ASD2)

\begin{tabular}{lllll}
\hline \multicolumn{1}{c}{ Benchmark } & PM & BL & Target \\
\hline $1 \quad \begin{array}{l}\text { The distance from the site } \\
\text { to the main road is within }\end{array}$ & & 1 & 1 \\
& & & \\
1,500 m. & & & \\
Providing pedestrian & 1 & 1 & 2 \\
access that leads from the \\
site to areas other than the \\
main road, which may be \\
a secondary road and/or an \\
adjacent area belonging to \\
another owner, so that \\
there is pedestrian access \\
from the site to at least \\
three public facilities \\
within the distance of 300 \\
m.
\end{tabular}

Table 4. Assessment of the Category of Public Transportation (ASD3)

\begin{tabular}{|c|c|c|c|c|}
\hline & Benchmark & PM & BL & Target \\
\hline $1 \mathrm{~A}$ & $\begin{array}{l}\text { There is a bus stop or } \\
\text { public transportation } \\
\text { station within } 300 \mathrm{~m} \\
\text { (walking distance) from } \\
\text { the gate of the building } \\
\text { location without } \\
\text { considering the length of } \\
\text { pedestrian bridges and } \\
\text { ramps. or }\end{array}$ & 1 & 1 & $1 \mathrm{~A}$ \\
\hline $1 \mathrm{~B}$ & $\begin{array}{l}\text { Providing a number of } \\
\text { shuttle buses for the } \\
\text { building's permanent } \\
\text { users; the number of the } \\
\text { buses has to be adequate } \\
\text { for serving } 10 \% \text { of all the } \\
\text { building's permanent } \\
\text { users. }\end{array}$ & 1 & - & 1B \\
\hline 2 & $\begin{array}{l}\text { Providing a pedestrian } \\
\text { path that is safe and } \\
\text { comfortable from the } \\
\text { building area to the } \\
\text { nearest public } \\
\text { transportation station by } \\
\text { considering Regulation of } \\
\text { the Minister of Public } \\
\text { Works Number } \\
\text { 30/PRT/M/2006 } \\
\text { Regarding Technical } \\
\text { Guidelines for the } \\
\text { Facilities and } \\
\text { Accessibility in Buildings } \\
\text { and the Environment } \\
\text { Appendix 2B. }\end{array}$ & 1 & 11 & 2 \\
\hline & $\begin{array}{l}\text { PM: point-max } \\
\text { BL: baseline }\end{array}$ & & & \\
\hline
\end{tabular}

As shown in the assessment of the category of public transportation in Table 4, in front of the market, there is a bus stop within $300 \mathrm{~m}$ from the site. The bus stop is located on Jalan Jata. The infrastructure facilities for bicycle users is the benchmark in the sub-criterion of bicycle user facilities as shown in Table 5. The Green Building concept requires that a public market have 1 unit of bycicle parking lot per 20 users of the building and 1 bathroom with a shower per 10 units of bicycle parking lots. The second requirement has not yet been fulfilled. Therefore, the Planning of Gianyar Public Market in this category does not get any point.

Table 5. Assessment of the Category of Bicycle Users (ASD4) 


\begin{tabular}{|c|c|c|c|c|}
\hline \multicolumn{2}{|r|}{ Benchmark } & PM & BL & Target \\
\hline 1 & $\begin{array}{l}\text { There are secure bicycle } \\
\text { parking lots the number } \\
\text { of which is } 1 \text { unit per } 20 \\
\text { building users. The } \\
\text { maximum number of } \\
\text { the units is } 100 \text {. }\end{array}$ & 1 & 11 & 1 \\
\hline 2 & $\begin{array}{l}\text { If the above } \\
\text { benchmark is met, it } \\
\text { is necessary to } \\
\text { provide } 1 \text { unit of } \\
\text { shower per ten } \\
\text { bicycle parking lots. }\end{array}$ & 1 & 11 & 2 \\
\hline Notes: & $\begin{array}{l}\text { PM: point-max } \\
\text { BL: baseline }\end{array}$ & & & \\
\hline
\end{tabular}

The benchmark in the sub-criterion of the landscape on the site category is the existence of a landscape area with softscape, which is free from hardscape and whose area is a minimum of $40 \%$ of the total area of the site, as shown in Table 6.

Table 6. Assessment of the Category of Landscape on the Site (ASD5)

\begin{tabular}{|c|c|c|c|c|c|}
\hline & Benchmark & PM & & BL & Target \\
\hline $1 \mathrm{~A}$ & $\begin{array}{l}\text { There is a landscape area in } \\
\text { the form of vegetation } \\
\text { (softscape) that is free from } \\
\text { garden structures (hardscape) } \\
\text { and whose area is a } \\
\text { minimum of } 40 \% \text { of the total } \\
\text { area of the site. The area of } \\
\text { the landscape includes that of } \\
\text { the gardens specified in } \\
\text { Prerequisite } 1 \text {, namely } \\
\text { gardens above the basement, } \\
\text { roof gardens, terrace gardens, } \\
\text { and vertical gardens, } \\
\text { according to the Regulation } \\
\text { of the Minister of Public } \\
\text { Works Number } \\
\text { 5/PRT/M/2008 on Green } \\
\text { Open Space, Article } 2.3 .1 \text { on } \\
\text { the Criteria of Vegetation for } \\
\text { Yards. }\end{array}$ & 1 & 1 & 1 & $1 \mathrm{~A}$ \\
\hline 1B & $\begin{array}{l}\text { When the above } \\
\text { benchmark is met, each } \\
\text { additional } 5 \% \text { of the total } \\
\text { area of the site to the } \\
\text { landscape area will get } 1 \\
\text { point. }\end{array}$ & 2 & 1 & 2 & 1B \\
\hline 2 & $\begin{array}{l}\text { The use of mature plants } \\
\text { that have been cultivated } \\
\text { locally on the province } \\
\text { scale with the crown area } \\
\text { being } 60 \% \text { of the total } \\
\text { landscape area as specified } \\
\text { in benchmark } 1 \text { of ASD } 5 \text {. }\end{array}$ & 1 & 1 & 1 & 2 \\
\hline
\end{tabular}

$$
\text { BL: baseline }
$$

Table 7. Assessment of the Microclimate Category (ASD6)

\begin{tabular}{|c|c|c|c|c|}
\hline & Benchmark & PM & BL & Target \\
\hline $1 \mathrm{~A}$ & $\begin{array}{l}\text { Using various materials to } \\
\text { prevent the heat island } \\
\text { effect on the building's } \\
\text { roofing area, so that the } \\
\text { albedo score (solar } \\
\text { thermal reflectivity) can } \\
\text { be at least } 0.3 \text {, according } \\
\text { to the required calculation. }\end{array}$ & 1 & 1 & $1 \mathrm{~A}$ \\
\hline 1B & $\begin{array}{l}\text { Using green roof whose } \\
\text { area is } 50 \% \text { of the roofing } \\
\text { area that is not used for } \\
\text { mechanical electrical } \\
(\mathrm{ME}) \text {, calculated from the } \\
\text { area of the crown. } \\
\text { or }\end{array}$ & 1 & - & 1B \\
\hline 2 & $\begin{array}{l}\text { Using various materials to } \\
\text { prevent the heat island } \\
\text { effect on the non-roofing } \\
\text { pavement areas, so that the } \\
\text { albedo score (solar } \\
\text { thermal reflectivity) can } \\
\text { be at least } 0.3 \text {, according } \\
\text { to the required calculation. }\end{array}$ & 1 & 1 & 2 \\
\hline $3 \mathrm{~A}$ & $\begin{array}{l}\text { Design of the landscape is } \\
\text { in the form of vegetation } \\
\text { (softscape) on the main } \\
\text { pedestrian circulation. The } \\
\text { vegetation has the function } \\
\text { of protecting the users } \\
\text { from the heat from solar } \\
\text { radiation. }\end{array}$ & 1 & 1 & $3 \mathrm{~A}$ \\
\hline $3 \mathrm{~B}$ & $\begin{array}{l}\text { Design of the landscape is } \\
\text { in the form of vegetation } \\
\text { (softscape) on the main } \\
\text { pedestrian circulation. The } \\
\text { vegetation has the function } \\
\text { of protecting the users } \\
\text { from the exposure to } \\
\text { strong winds. }\end{array}$ & 1 & - & $3 B$ \\
\hline & $\begin{array}{l}\text { PM: point-max } \\
\text { BL: baseline }\end{array}$ & & & \\
\hline
\end{tabular}

The total area of the open space of Gianyar Public Market is $5,356 \mathrm{~m}^{2}$. The space consists of $835 \mathrm{~m}^{2}$ softscape and $4,521 \mathrm{~m}^{2}$ hardscape. The softscape is only $18.47 \%$ of the total area of the open space. In addition, other benchmarks, such as the use of local plants and locally cultivated plants in the market's area, have not yet been fulfilled. Therefore, in the sub-criterion, the design has not yet got a point because the softscape area is still less than $40 \%$ of the total area of the open space. 
The benchmark in the category of microclimate is that the albedo value on the roofing and nonroofing areas is at least 0.3 as shown in Table 7. The albedo values of Gianyar Public Market are as follows: 1) the roofing material in the form of ceramic roof has the albedo value of 0.4 and 2) the non-roofing materials in the forms of paved areas and green vegetation have the albedo value of 0.38 .

Materials with a high value of albedo or reflectivity absorb little radiation, so that much radiation is reflected. This results in an increase in temperature (Santi et al., 2019). The average albedo value of both the roofing and nonroofing materials is 0.39 . Besides calculating albedo values, the study also identified types of the vegetation planted on the main pedestrian circulation in the outdoor areas within the site to protect the users from heat from the sun.

Table 8. Assessment of the Category of Rainwater Runoff Management (ASD7)

\begin{tabular}{|c|c|c|c|c|c|}
\hline \multicolumn{2}{|r|}{ Benchmark } & \multicolumn{2}{|c|}{ PM } & & \multirow{2}{*}{$\frac{\text { Target }}{1 \mathrm{~A}}$} \\
\hline $1 \mathrm{~A}$ & $\begin{array}{l}\text { A reduction of up to } 50 \% \text { of } \\
\text { the load volume of the } \\
\text { rainwater runoff flowing to the } \\
\text { city drainage system from the } \\
\text { building site. It is calculated } \\
\text { by using the rainfall intensity } \\
\text { value of } 50 \mathrm{~mm} \text { per day. } \\
\text { or }\end{array}$ & 1 & & & \\
\hline 1B & $\begin{array}{l}\text { A reduction of up to } 85 \% \text { of } \\
\text { the load volume of the } \\
\text { rainwater runoff flowing to the } \\
\text { city drainage system from the } \\
\text { building site. It is calculated } \\
\text { by using the rainfall intensity } \\
\text { value of } 50 \mathrm{~mm} \text { per day. }\end{array}$ & 2 & 1 & 0 & $1 \mathrm{~B}$ \\
\hline 2 & $\begin{array}{l}\text { There are efforts to decrease } \\
\text { environmental flood loads } \\
\text { from outside the building site. }\end{array}$ & 1 & 1 & 1 & 2 \\
\hline 3 & $\begin{array}{l}\text { Using technologies to reduce } \\
\text { the discharge of rainwater } \\
\text { runoff. }\end{array}$ & 1 & 1 & 1 & 3 \\
\hline Notes & $\begin{array}{l}\text { PM: point-max } \\
\text { BL: baseline }\end{array}$ & & & & \\
\hline
\end{tabular}

There are no efforts and technology to reduce the load volume of rainwater runoff to the drainage network, so that in the category of rainwater runoff management, the Planning of Gianyar Public Market does not get any point, as shown in Table 8.

Results from the assessment by using GREENSHIP rating tools in the category of
Appropriate Site Development for New Buildings Version 1.2 show that the Planning of Gianyar Public Market gets 7 (seven) points out of the highest number of points, 17, or around $41.18 \%$. Therefore, it can be said that the market's planning has not yet fulfilled the standard criteria in the category of appropriate site development. Therefore, it is recommended that the market's planning incorporate some efforts to apply the Green Building concept, namely improving some aspects related to the categories that have not yet got any point or maximum points and applying some technologies to apply the Green Building concept. All these efforts are aimed at increasing the assessment point, being closer to the maximum rating (100\%).

\section{CONCLUSION}

To fulfill the assessment criteria, especially the ones relating to the benchmarks that have not yet been fulfilled, some efforts need to be taken. For the assessment in the category of public transportation, it is necessary to provide a bus stop that pedestrians can reach on Jalan Ngurah Rai. Currently, the nearest bus stop is on Jalan Jata, but it cannot be reached directly by pedestrians from the building site.

Facilities for bicycle users need to be improved by providing 56 units of secure bicycle parking lots. The number of the building users is 1120 and the benchmark relating to this is that there has to be 1 unit of bicycle parking lot per 20 users of the building. All this means that 56 units of parking lots already meets the benchmark. In addition, it is necessary to provide six units of showers to meet the relevant benchmark.

For the assessment in the category of landscape on the site, it is necessary to enlarge the vegetation area around the building up to $50 \%$ of the total area of the open space, above the percentage specified by the benchmark (40\%), so that the maximum point in the sub-criterion can be obtained. Therefore, the vegetation area that needs to be added to the site is $1,307.4 \mathrm{~m}^{2}$. Results of the volume calculation show that the maximum rainwater runoff is $103.86 \mathrm{~m}^{3}$ per day. To meet the minimum benchmark, at least $50 \%$ of the runoff or $51.93 \mathrm{~m}^{3}$ of it per day has to be contained in the building area. One of the 
ways to contain the runoff is building infiltration wells, through which the runoff enters the soil.

\section{REFERENCE}

Amalia, A. A., Amal, C. A., Fuadillah, S., \& Amin, A. (2018). Evaluasi Aspek Tepat Guna Lahan Pada Mall Nipah Makassar Dengan Menggunakan Greenship Rating Tools. 7-14.

Andini, R., \& Utomo, C. (2014). Analisa Pengaruh Penerapan Konsep Green Building Terhadap Keputusan Investasi pada National Hospital Surabaya. Jurnal Teknik POMITS, 3(2), C53-C56.

Anggunmulia, R., Widyanto, D. S., Chandra, H. P., \& Ratnawidjaja, S. (2015). Kriteria bangunan hijau dan tantangannya pada proyek konstruksi di Surabaya. Dimensi Pratama Teknik Sipil, 4, 1.

Arafat, S. A., \& Syamsiyah, N. R. (2015). Performansi Greenship Building Pada Rumah Turi Di Surakarta (Penekanan Pada Water Concervation Dan Material Resource and Cycle). Sinektika: Jurnal Arsitektur, 13(1), 11-18. https://doi.org/10.23917/sinektika.v13i1. 694

Dianita, R., Lilo, T., \& Sucipto, A. (2014). Analisa Pemilihan Material Bangunan Dalam Mewujudkan Green Building ( Studi Kasus : Gedung Kantor Perwakilan Bank Indonesia Solo ). Jurnal Pendidikan Teknik Bangunan, 4.

Firsani, T., \& Utomo, C. (2012). Analisa Life Cycle Cost pada Green Building Diamond Building Malaysia. Teknik ITS, 1(September (2012)), D34-D38.

Frej, A. B., Browning, W. D., \& Urban Land Institute. (2005). Green office buildings: a practical guide to development. ULI.

GREENSHIP. (2013). GREENSHIP untuk BANGUNAN BARU, Ringkasan Kriteria dan Tolok Ukur (Versi 1.2, Issue April). Divisi Rating dan Teknologi, Green Building Council Indonesia.

Kurniati, D., Sucipto, T. L. A., \& Murtiono, E. S. (2014). Studi Implementasi Green Building Di Universitas Sebelas Maret Surakarta. Pendidikan Teknik Bangunan, 3(3), 1-12.

Mahi, Al. K. (2017). Perencanaan
Pembangunan Daerah Teori dan Aplikasi (I). Kencana.

Nasir, R. Y. (2016). Sekilas Tentang Green Building.

Nastiti, J. A., Setiono, J., \& Lydianingtias, D. (2020). Kelayakan Teknis Dengan Parameter " Greenship Rating Tools " Dan Kelayakan Finansial Perumahan Adyna Residence. 1(September), 134139.

Peraturan Daerah Kota Gianyar No. 16 tahun 2012 tentang rencana tata ruang wilayah kabupaten Gianyar Tahun 2012-2023, (2012).

Peraturan Menteri Pekerjaan Umum Nomor: 14/PRT/M/2013 Tentang Standar dan Pedoman Pengadaan Pekerjaan Konstruksi dan Jasa Konsultansi, (2013).

Peraturan Kementerian Lingkungan Hidup No. 8 Tahun 2010. 2010. Kementerian Lingkungan Hidup.

Peraturan Menteri Pekerjaan Umum Noor 05/PRT/M/2008 Tentang Pedoman Penyediaan Dan Pemanfaatan Ruang Terbuka Hijau Di Kawasan Perkotaan. 2008.

Permendagri Nomor 1 Tahun 2007 Tentang Penataan Ruang Terbuka Hijau Kawasan Perkotaan. 2007.

Ratnaningsih, A., Hasanuddin, A., \& Hermansa, R. (2019). Penilaian Kriteria Green Building Pada Pembangunan Gedung IsDB Project Berdasarkan Skala Indeks Menggunakan Greenship Versi 1.2 (Studi Kasus: Gedung Engineering Biotechnology Universitas Jember). Berkala Sainstek, 7(2), 59. https://doi.org/10.19184/bst.v7i2.12153

Rinaldi. (2019). Gaung Bangunan Hijau di Daerah Masih Rendah. Newrei.

Santi, S., Belinda, S., \& Rianty, H. (2019). Identifikasi Iklim Mikro Dan Kenyaman Termal Ruang Terbuka Hijau Di Kendari. NALARs, 18(1), 23. https://doi.org/10.24853/nalars.18.1.2334

Shiers, D. E. (2000). "Green" developments: Environmentally responsible buildings in the UK commercial property sector. Property Management. https://doi.org/10.1108/02637470010360 650

Surjana, T. S., \& Ardiansyah, A. (2013). 
Perancangan Arsitektur Ramah

Lingkungan: Pencapaian Rating

Greenship GBCI. Jurnal Arsitektur

Universitas Bandar Lampung, 2(3), 1-14.

Sutedi, A. (2009). Metode Penelitian Hukum.

Sinar Grafika.

Teddy, S. D., Priatman, J., \& Susilo, N. (2018).

Kajian Penerapan Prinsip Water

Conservation Sesuai Standar Greenship

New Building Versi 1.2 Studi Kasus:

Gedung P1 Dan P2 Universitas Kristen

Petra Surabaya. Dimensi Utama Teknik

Sipil, 5(2), 9-16.

https://doi.org/10.9744/duts.5.2.9-16

Zainol, N. N., Mohammad, I. S., Baba, M., Woon, N. B., \& Nazri, A. Q. (2015).

Green cleaning: An essential aspect of

Malaysian green buildings. Jurnal

Teknologi, 75(10), 65-70.

https://doi.org/10.11113/jt.v75.5274 